\title{
Subjek Pendidikan dalam Perspektif Al-Qur'an (Suatu Kajian dari Surah al-Najem Ayat 5 - 11)
}

\author{
H. M. Amir HM 1 * \\ ${ }^{1}$ Pendidikan Agama Islam, Fakultas Tarbiyah, IAIN Bone. Jl. HOS Cokroaminoto, Kab. Bone, \\ Sulawesi Selatan, Indonesia. \\ * Korespondensi Penulis. E-mail: amirhm@iain-bone.ac.id
}

\begin{abstract}
Abstrak
Kajian al-Qur'an surah An-Najm ayat 5 - 11 mengisyaratkan bahwa Malaikat Jibril berfungsi sebagai subjek pendidilan, karena beliau yang menyampaikan dan mengajarkan wahyu kepada Muhammad saw. Sebagai subjek pendidikan beliau memiliki kekuatan fisik dan rohani yang prima dan kecerdasan akal yang cemerlang, wawasan keilmuan yang luas serta kuat hapalannya, sehingga tidak ada keraguang bahwa apa yang disampaikan dari Allah kepada Muhammad terdapat perubahan, kekeliruan atau kesalahan. Selain Jibril memiliki integritas keilmuan yang mumpuni, juga memiliki kepribadian yang mantap, sehingga siapapun yang berfungsi sebagai subjek pendidikan seharusnya menjadikan contoh dalam melaksankan tugas yang mulia itu. Salah satu dianta adalah sikap rendah hati atau tawadhu'. Hal ini terlihat ketika Jibril berada pada posisi yang jauh yakni tempat terbitnya matahari, namun Muhammad sudah bisa melihatnya, dalam arti pada posisi seperti itu sudah bisa terjadi komunikasi antara keduanya, tetapi dengan sikap ketawadhuannya, beliau mendekati Muhammad saw. sebagai objek pendidikan ketika itu, sampai jarak antara keduanya hanya sebatas dua busur anak panah, baru Jibril menyampaikan atau megajarkan wahyu kepada Muhmmad saw. sebagaimana yang seharusnya disampaikan atau diajarkan.
\end{abstract}

Kata Kunci: subjek, pendidikan, al-quran

\section{Education Subjects in the Qur'anic Perspective (A Study from Surah al-Najem Verses 5 - 11)}

\begin{abstract}
The study of the Koran surah An-Najm verses 5-11 suggests that the Angel Gabriel functions as the subject of the hearing, because he delivered and taught revelations to Muhammad. As an educational subject, he has excellent physical and spiritual strength and brilliant intelligence, broad scientific insight and strong memorization, so there is no doubt that what was conveyed from Allah to Muhammad there were changes, errors or mistakes. In addition to Gabriel has qualified scientific integrity, also has a strong personality, so anyone who functions as an educational subject should set an example in carrying out this noble task. One of them is humble attitude or tawadhu'. This can be seen when Gabriel is in a distant position that is the place where the sun rises, but Muhammad was able to see it, meaning that in such a position communication can occur between the two, but with his attitude of devotion, he approached Muhammad. as an object of education at that time, until the distance between the two was limited to two arrows, then Gabriel delivered or taught revelations to the Muhmmad. as it should be said or taught.
\end{abstract}

Keywords: subjek, pendidikan, al-quran 


\section{PENDAHULUAN}

Kajian terhadap al-Qur'an selalu bersifat terbuka dan tidak pernah selesai, karena pemahaman selalau berkembang, seiringan dengan perkembangan umat Islam yang selalu terlibat dalam penafsiran ulang dari masa ke masa. Hal ini menunjukkan tidak semua doktrin dan pemahaman agama akan berlaku pada setiap waktu dan tempat, karena bahasa al-Qur'an bersifat lokal-kultural, sehingga reinterpretasi akan terus terjadi untuk mengungkap pesan-pesan universal. Hal inilah yang menjadikan al-Qur'an bisa diterima di mana pun dan kapan pun. ${ }^{1}$

Kandungan al-Qur'an yang bersifat universal itu, menjadikannya tidak pernah kering untuk dikaji. Semakin dikaji, semakin tidak terjangkau kedalamannya. Sama halnya seorang yang menyelam di laut lepas, semakin jauh dari pinggir laut semakin tidak dapat menjangkau kedalamannya. Namun, orang yang menyelam itu berusaha terus menerus untuk menjangkau kedalaman laut itu, setidanya tetap berusaha menemukan nilai-nilai mutiara dari dasar laut tersebut. Demikian halnya dengan kajian al-Qur'an, sekali pun tidak dapat dijangkau kedalaman kandungannya, tetapi setiap mengkaji alQur'an, setidaknya terdapat hikmah-hikmah yang cemerlang yang didapatkan dari al-Qur'an itu, karena al-Qur'an hadir menemui umat manusia, di dalamnya terdapat berbagai hikmah dan mutiara yang dapat menyinari kehidupan mereka, sekaligus menawarkan jalang keluar setiap permasalahan yang dihadapinya.

Salah satu hikmah dan mutiara yang terdapat dalam al-Qur'an adalah masalah pendidikan yang tidak bisa terpisahkan dari kehidupan umat manusia. Sejak manusia dalam kandungan ibunya sampai lahir di dunia, bahkan sampai akhir hayatnya memerlukan bimbingan dari luar dirinya. Karena itu, menurut Rasyid Ridha pendidikan adalah bimbingan daya manusia baik jasmani, akhlak maupun jiwa yang menjadikan tumbuh dan berkembang serta bergerak sehingga sampai kesempurnaan dirinya. $^{2}$

Istilah pendidikan dalam Islam sering diistilahkan dengan al-Tariyah yang berarti pendidikan, juga sering disebut dengan al-Ta'limiyah yang berarti pengajaran, juga terkadang disebut dengan alTa'dibiyah yang berarti pendidikan sopan santun. Dengan demikian yang dimaksud pendidikan adalah suatu proses untuk merubah dan mengembangkan potensi dasar yang terdapat dalam diri manusia, baik potensi jasmaniyah, maupun rohaniyah guna memperoleh kesempurnaan dirinya sebagai khalifah Allah, untuk membangun dan memakmurkan dunia, sekaligus sebagai hamba Allah untuk beribadah kepada-Nya.

Karena itu, pendidikan yang ideal adalah pendidikan yang dapat menjadikan manusia potensial dengan kepribadian luhur, sikap dan prilau yang baik sehaingga mampu manjadikan dirinya sebagai manusia seutuhnya, yakni manusia yang sehat jasmani dsan rohani, sehat mental dan spiritual, seheingga mereka mampu mensingkrongkan antara kepentingan kehdiupan di dunia dan di akhirat. Itula sebabnya, sehingga yang menjadi tujuan akhir pendidikan termasuk pendidikan Islam adalah terbentuknya pribadi-pribadi yang berakhlak mulia yang menjadi nilai dasar bagi peserta didik sehingga menjadi kebiasaan bagi mereka dalam semua tingkah kalu dan selalu mengedepankan nilainilai moral dari pada kepentingan material. ${ }^{3}$

Untuk mewujudkan tujuan pendidikan tersebut, diperlukan adanya pendidik atau yang menjadi subjek pendidikan yang handal dan professional ${ }^{4}$ dalam arti memiliki skill dan keahlian dalam bidang pendidikan, sehat jasmani dan rohani, memiliki akal yang cerdas dan wawasan keilmuan yang luas serta dapat memfungsikan dirinya sebagai qudwatan bagi peserta didiknya. Itulah sebabnya fungsi pendidik tidak dapat digantikan oleh hasil tekonologi secanggih apa pun, misalnya mesin, robot, Tv

${ }^{1}$ Ali Imron, Semiotika Al-Qur'an Metode dan Aplikasi Terhadap Kisah Yusuf (Cet I; Yogyakarta: Sukses Offset, 2011), h. 1

${ }^{2}$ Rasyid Ridha, Al-Tarbyah al-Islamiyah al-Ta'lim al-Islamiyah, XXXIV No. 7 (t.t: al-Manar, 1935), h. 544-345

${ }^{3}$ Muhammad Takdir Ilahi, Revitalisasi Pendidikan Berbasis Moral (Cet. I; Jogjakarta: Ar-Ruzz Media, 2012), h. 45-46. s

${ }^{4}$ Secara etimologi, berasal dari kata profesi, dalam bahasa Inggeris profession dan dalam bahasa latin profecus yang berarti mengakui, pengakuan, menatakan mampu atau ahli dalam melaksanakan pekerjaan tertentu. Sudirman Damin, Inovasi Pendidikan dalam Upaya Peningkatan Profesionalisme Tentang Kependidikan (Cet. I; Jakarta: Pustaka Setia, 2002), h. 20-21 
dan radio. Seorang pendidik menjadi bintang utama yang akan diidolakan oleh peserta didiknya. Fungsi seorang pendidik tidak hanya mengisi otak peserta didik dengan berbagai ilmu pengetahuan atau hanya memiliki kecerdasan intlektual, tetapi lebih dari itu, peserta didik harus meliki kecerdasan emosional, spiritual dan sosial. Karena itu, dalam tulisan ini berusaha menelusuri makna-makna ayat yang terdapat dalam surah An-Najm yang terkait dengan subjek pendidikan, sebagai salah satu usaha untuk membuktikan bahwa al-Qur'an merupakan sumber normatif pendidikan Islam.

\section{HASIL DAN PEMBAHASAN}

Surah An-Najm merupakan surah ke 53. Penamaan surah An-Najm diambil dari awal kata surah ini yang merupakan salah satu surah seluruh ayatnya turu sebelum Nabi Muhammad saw. berhijrah ke Madinah, sehingga dikategorikan sebagai surah makkiyah. Tema utama surah ini adalah sama dengan tema-tema surah makkiyah lainnya, yakni berbicara tentang akidah, keesaan Allah, kenabian dan keniscayyaan hari kiamat. ${ }^{5}$

Dalam kaitan dengan kajian pendidikan terdapat beberapa ayatnya yang terkait dengan subjek pendidikan yang menarik untuk dikaji mutiara-mutiara yang terkandung di dalamnya untuk diaktualisasikan dalam dunia pendidikan dewasa ini, sekaligus menunjukkan kesakralan al-Quran sebagai dasar normatif pendidikan Islam. Ayat yang menjadi fokus dalam tulisan ini adalah ayat 5 11 yang secara utuh dapat dilihat sebagai berikut:

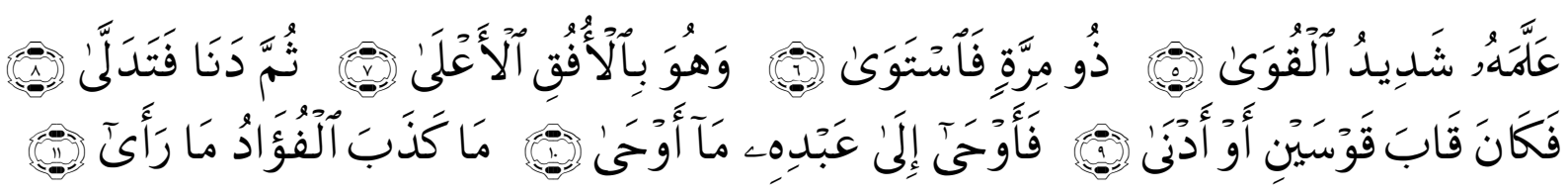

"Artinya: (5) yang diajarkan kepadanya oleh (Jibril) yang sangat kuat, (6) yang mempunyai keteguhan; maka (Jibril itu) menampakkan diri dengan rupa yang asli (rupa yang bagus dan perkasa). (7) Sedang dia berada di upuk yang tinggi. (8) Kemudian dia mendekat (pada Muhammad), lalu bertambah dekat, (9) sehingga jaraknya (sekitar) dua busur panah atau lebih dekat (lagi). (10) Lalu disampaikannya wahyu kepada hamba-Nya (Muhammad) apa yang telah diwahyukan kepada Allah. (Hatinya) tidak mendustakan apa yang telah dilihatnya.",

Ayat- ayat tersebut mengandung makna subjek pendidikan yakni Jibril, Karen pada waktu itu yang mengajar atau menyampaikan wahyu kepada Muhammad adalah Jibril dengan berbagai karakteristiknya yang dapat memberi inspirasi bagi pelaku (sujek) pendidikan dewasa ini yang rinciannya dapat dilihar sebagai berikut:

\section{1. القوئ ('allamahu syadid al-quwaa)}

('allamahu syadid al-quwaa) term al-Quwa berasal dari kata qawiyyun yang berakar dari huruf qaf, wau dan ya yang berarti khilaf al-dhaif yakni lawan dari lemah ${ }^{7}$ yang berarti kuat. Menurut al-Maragy yang dimaksud syadid al-quwa pada ayat ini adalah Jibril yang memiliki kuakuatan hebat dari segi ilmunya secara teoritis maupun peratiksi yakni apa yang diketahui juga diamalkan atau sesuai ucapan dan perbuatan. ${ }^{8}$ Selain kekuatan ilmu pengetahuan, juga Jibril memiliki kekuatan fisik dan kekuatan rohani, sehingga kitaka mengajar Muhammad dalam arti menyampaiakan wahyu dari Allah swt. berada dalam posisi prima, terutama dari kekuatan ilmunya yang menyebabkan wahyu yang disampaikan kepada Muhammad saw. sesuai dengan apa yang diterima dari Allah swt. Menurut M. Quraish Shihab, bahwa Jibril mengajarkan kepada Muhammad al-Qur'an, bukan berarti wahyu itu bersumber dari Jibril, melainkan berasal dari Allah. Sering kali seorang pengajar mengajarkan sesuatu bukan bersumber dari dirinya, melainkan dari orang lain. Misalnya seorang guru mengajar anak membaca, padahal apa yang diajarkan itu bersumber dari karya orang lain. Karena itu, menyampaikan

${ }^{5}$ M. Quraish Shihab, Tafsir Al-Misbah Pesan, Kesan dan Keserasian Al-Qur'an, Vol. 13 (Cet. III; Letera Hati: Ciputat- Tangerang, 2005), h. 405.

${ }^{6}$ Departemen Agama RI., Al-Qur'an dan Terjemahnya (Toha Putra: Semarang, 2002), h. 763.

${ }^{7}$ Abi al-Husain Ahmad bin Faris bin Zakariya, Mu'jam Maqayis al-Lugah, JIlid V (Dar al-Jil: Bairut, 1420 H./1999 M.), h. 36 - 37

${ }^{8}$ Ahmad Mushthafa al-Maragy, Tafsir al-Maragy, jilid 27 (Mushthafa al-Bab al-Halabi: Mesir, t.th), h. 
sesautu secara baik dan benar meruapan salah satu bentuk pengajaran. Malaikat Jibril menerima wahyu dari Allah kemudian menyampaikan kepada Muhammad secara baik dan benar, merupakan salah satu bentuk pengajaran. ${ }^{9}$ Itulah sebabnya dalam ayat ini Jibril dikategorikan sebagai subjek pendidikan.

Karena itu, setiap orang yang menjadi subjek pendidikan atau pendidi seharunya memiliki ilmu pengetahuan yang mumpuni di bidangnya atau memiliki kamampun dan kecakapan, sebagai bagian dari kompetensi ${ }^{10}$ seorang pendidik, ketika mengajar seharusnya apa yang disampaikan itu adalah sesuatu yang diyakini kebenarannya dan bersumber dari referensi yang benar. Untuk mewujudkan hal ini diperlukan kekuatan fisik dan psikis yang mamadai. Menurut Zakiah Darajat seperti yang dikutip oleh Ramayulis bahwa kesehatan badan sangat mempengaruhi semangat kerja. Guru yang sakitsakitan kerap sekali terpaksa absen dan tentunya akan merugikan anak-anak. ${ }^{11}$ Karena itu, adalah sesuatu yang sangat wajar ketika seseorang yang akan diserahi tanggung jawab sebagai subjek pendidikan menjadi salah satu persyaratan utamanya adalah sehat jasmani dan rohani.

2. ذو مرة فأستـوئ (zuumirratin fastawa)

(zuumirratin fastawa) Term mirratin berakar kata dari huruf mim, ra dan al-harf al-mu'tal yang berarti sesuatu yang sangat kuat. ${ }^{12}$ Juga berarti memiliki pandangan yang bagus, dan kekuatan yang prima. ${ }^{13}$ M. Quraish Shihab mengartikan kata mirratin dengan melilitkan tali guna menguatkan sesuatu. Kata ذو مرة digunakan untuk menggambarkan kekuatan nalar dan tingginya kemampuan seseorang, yang terdiri dari kekuatan fisik, akal dan nalar. ${ }^{14}$ Kekuatan fisik Jibril dapat dibuktikan antara lain ia pernah mencopot dan mengangkat tanah kawasan kaum Nabi Lut, dipinggulnya di atas sayapnya, kemudian membalikkannya menimpa kaum Lut, dan juga meneriakkan suaranya yang sangat dahsyat kepada kaum Samud, sehingga mereka musnah, teriakan dahsyat sebagai azab kepada kaum samud. ${ }^{15}$ Sedangkan dari segi kekuatan nalarnya seperti digambarakan oleh al-Maragy menyatakan bahwa term tersebut menggambarkan tentang kekuatan pikiran Jibril yang demikian mengagungkan. ${ }^{16}$ Jibril memiliki pemikiran yang kuat dan pandangan yang baik. ${ }^{17}$

Dari uraian di atas, dipahami bahwa Jibril memiliki kekuatan fisik, pikiran dan nalar yang luar biasa dan pandangan yang demikian cemerlang, sehigga tidak ada ruang sedikitpun terjadinya perubahan lafadz-lafadz atau kalimat, bahkan huruf al-Qur'an yang diterima dari Allah swt. dan disampaikan kepada Nabi Muhammad saw. Karena itu, tidak boleh ada pemikiran di kalangan umat manusia bahwa kemungkinannya ada ayat yang beliau lupa, tercecer ataupun sengaja disembunyikan. Jibril khusus ditugaskan oleh Allah swt. menyampaikan wahyu kepada nabi dan rasul-Nya tidak terkecuali Nabi Muhammad saw. yang telah dibekali dengan kekuatan fisik dan kemampuan akal dan Jibril telah malaksanakan tugas itu dengan baik dan itulah makna فـاستـوئ (fastawa) pada ayat tersebut.

Term Istawa berasal dari kata sawa terdiri dari huruf sin, wau dan al-Harf al-Mu'tal yang berarti tetap atau lurus di antara keduanya. ${ }^{18}$ Jibril menampakkan diri dalam bentuk yang asli, seperti halnya ketika Nabi berada di Gua Hira pada permulaan kenabiannya. ${ }^{19}$ Pada dasarnya Jibril tidak mengalami perubahan, terutama dari segi kecerdasannya dan kemampuan intlektualnya. Ini berarti apa

${ }^{9}$ M. Quraish Shihab, Tafsir Al-Misbah, vol. 13, h. 410 - 411

${ }^{10}$ Sebagai perilaku yang rasional untuk mecapai suatu tujuan yang dipersyaratkan sesuai dengan kondisi yang diharapkan. Kopotensi guru merupakan kemampuan seorang guru dalam melaksanakan kewajiban secara bertanggung jawab dan layak di mata pemangku kepentingan. Lihat Suyanto dan Asep Jihad, Menjadi Guru Profesional Strategi Meningkatkan Kualifikasi dan Kuslitas Guru di Era Global (Gapprint: Jakarta: 2013), h. 1

${ }^{11}$ Ramayulis, Profesi dan Etika Keguruan (Cet. VII; Radar Jaya Offset: Jakarta, 2013), h. 8

${ }^{12}$ Abi al-Husain Ahmad bin Faris bin Zakariya, Mu'jam Maqayis al-Lugah, jilid 5, h. 214

${ }^{13 ،}$ 'Imad al-Din al-Fidai IIsma'il ibn Katsir al-Qurasyy al-Dimsyqy, Tafsir Al-Qur'an al- 'Azhim, Jilid 4 (t.tp: Dar al-Fikr, t.th), h. 247

${ }^{14}$ M. Quraish Shihab, Tafsir Al-Misbah, Vol. 13, h. 411

${ }^{15}$ Kementerian Agama RI. Al-Qur'an dan Tafsirnya, Jilid 9 (Jakarta: Lentera Hati Abadi, 2010), h. 528.

${ }^{16}$ Ahmad Mushthafa al-Maragy, Tafsir al-Maragy, jilid 27, h. 46

${ }^{17} \mathrm{Jalal}$ al-Din Muhammad bin Ahmad al-Mahally dan Jalal al-Din 'Abdu al-Raham bin Aby

Bakar al-Suyuty, Tafir al-Qur'an al-Karim (al-Sikapiyyah: Surabaya, t.th), h. 197

${ }^{18}$ Abi al-Husain Ahmad bin Faris bin Zakariya, Mu'jam Maqayis al-Lugah, jilid III, h. 112

${ }^{19}$ Ahmad Mushthafa al-Maragy, Tafsir al-Maragy, jilid 27, h. 42 
yang disampaikan Jibril kepada Muhammad adalah sesuatu yang valid dan bersumber dari Allah swt. Karen itu, salah satu hikmah al-Qur'an diturunkan secara beransur-ansur untuk memudahkan Jibril menghafal sekaligus menjaga keorsinalan ayat-ayat yang disampaikan kepada Muhammad saw.

Dari Keterangan di atas dipahami bahwa setiap orang yang menjadi subjek pendidikan, harus memiliki kemampuan intlektual, dan wawasan yang luas, sehingga mampu menyampaikan sesatu dengan benar, bersumber dari referensi yang valid dan harus memiliki sikap konsistensi dalam bersikap termasuk ketika mengajar atau mentransfer ilmunya kepada orang lain.

Dengan dmikian, setiap pendidik harus berusaha menjadi pendidik yang professional, yakni pendidik yang melekat padanya integritas keilmuan dan kepribadian yang mumpuni, sehingga setiap pendidik harus memiliki setandar minimal intgritas keilmuan, yakni:

(1) Memiliki kemampuan intlektual yang baik, (2) memiliki kemampuan memahami visi dan misi pendidikan, (3) memiliki keahlian mentransfer ilmu pengetahuan kepada peserta didik, (4) memahami konsep perkembangan psikologi anak, (5) memiliki kemampuan mengorganisasi proses belajar, (6) memiliki kreativitas dan seni mendidik. ${ }^{20}$

Selain itu, seorang pendidik juga harus memiliki kompetensi kepribadian yang mumpuni seperti halnya yang ditunjukkan oleh Jibril. Kompetensi kepribadian dimaksud, antara lain; ulet, tangguh, tabah menghadapi tantangan dan kesulitan, cepat bangkit apabila mengalami kegagalan, memiliki etos belajar dan etos kerja yang tinggi, berpikir positif terhadap orang lain, bersikap seimbang antara mengambil dan memberi dalam hubungan sosial dan memiliki komitmen atau tanggung jawab. ${ }^{21}$

Apa bila kompetensi integritas keilmuan dan kepribadian yang mumpuni dimiliki oleh para pendidik, maka akan berdampak terhadap pengembangan ilmu pengetahuan, baik bagi pendidik maupun terhadap peserta didik dan dirasakan bukan saja bagi manusia sebagai kahalifah Allah di muka bumi ini, tetapai juga terhadap seluruh makhluk Allah swt. Karena integritas keilmuan dan kepribadian seseorang, akan bermakna ketika dimanfaatkan untuk berhubungan dengan Allah dalam bentuk ibadah, dan juga terhadap sesama manusia dalam bentuk intraksi sosial dan sesama makhluk lain dalam bentuk kasih saying.

3. وهو بـالافق الاعلئ ثم دنـا فتــ لـئ (wa huwa bi al-ufuq al-a'la stumma dana fatadallaa)

(wa huwa bi al-ufuq al-a'la stumma dana fatadallaa) Term ufuk terbentuk dari huruf alif, fa dan qaf yang berarti sesuatu yang berjauhan di antara dua pinggirnya. ${ }^{22}$ Sedangkan Term dana adalah fi'il al-madi yng terdiri dari huruf dal, nun dan al-harf almu'tal yang berarti (almuqarabah) yakni berdekatan. ${ }^{23}$ Menurut al-Maragy bahwa Jibril menampakkan dirinya kepada Rasulullah dalam bentuk asli pada ufuk yang tertinggi yaitu ufuk tempat terbitnya matahari, tetapi Rasulullah dapat melihatnya, kemudian Jibril mulai mendekat kepada Rasululah saw. lalu bertambah dekat. ${ }^{24}$

Dari uraian di atas memberi pelajaran bagi mereka yang menjadi pendidik atau subjek pendidikan, bahwa mereka harus selalu menempatkan dirinya pada posisi tertinggi dibanding dengan peserta didik. Kalau posisi tempat tentu tidak ada manusia biasa yang bisa menyerupai Jibril, tetapi dalam pengertian maknawi mereka yang menjadi subjek pendidikan harusnya memposisikan dirinya pada posisi tertinggi dibanding dengan peserta didik. Misalnya dari segi integritas keilmuan dan kompotensi kepribadian harusnya mereka lebih tinggi atau lebih unggul dari peserta didiknya, sehingga menjadi qudwatan (suri teladan) di manapun mereka berada. Namun demikian, selayaknya mereka tidak menjaga jarak dengan peserta didiknya, sebaiknya mereka bergaul dan berkomunikasi, berbincang dan berdiskusi, namun dalam batas-batas kewajaran, sikap hormat tetap harus dijunjung tinggi oleh peserta didik sebagai orang yang menuntut ilmu pengatahuan, dan bagi pendidik harus menunjukkan kasih sayang terhadap peserta didiknya, sebagai orang yang menjadi sumber ilmu pengetahuan.

\footnotetext{
${ }^{20}$ Suyanto dan Asep Jihad, Menjadi Guru Profesional, h. 5

${ }^{21}$ Ramayulis, Propesi dan Etika Keguruan, h, 55

${ }^{22}$ Abi al-Husain Ahmad bin Faris bin Zakariya, Mu'jam Maqayis al-Lugah, jilid I, h. 114

${ }^{23}$ Abi al-Husain Ahmad bin Faris bin Zakariya, Mu'jam Maqayis al-Lugah, jilid II, h. 303

${ }^{24}$ Ahmad Mushthafa al-Maragy, Tafsir al-Maragy, jilid 27, h. 42
} 
Kalau nilai-nilai kepribadian kedua belah pihak tersebut, terwujud dalam kehidupan mereka, maka terjadilah kedekatan yang harmonis, sehingga menjadi sumber berkahnya ilmu pengetahuan, baik bagi pendidik maupun peserta didik. Sebagaimana yang dialami oleh Rasulullah saw. Beliau menjadi penuntun bukan saja di kalang suku atau bangsanya, tetapi seluruh suku dan bangsa di dunia ini, bukan saja menjadi rahmat di kalangan umatnya, tetapi juga menjadi rahmat di seluruh umat manusia. Kasemuanya itu terwujud berkat sinaran ilmu yang diperoleh dari Jibril Alaissalam melalui dengan al-Qur'an.

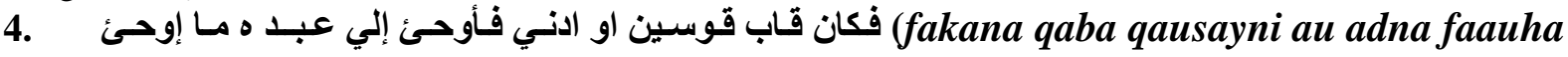 ila 'abdihi maauha)}

(fakana qaba qausayni au adna faauha ila 'abdihi maauha) menurut M. Quraish Shihab, Term qusaini adalah bentuk mustanna dari kata mufradnya qausun yang berarti busur fana, sebagai ungkapan untuk menunjukkan kedekatan yang luar biasa. Kemudian Allah swt. mewahyukan kepada hamba-Nya melalui malikat Jibril apa yang diwayukan. Sedangkan Term ma auha mengisyaratkan bahwa yang disampaikan itu adalah sesuatu yang sangat agung, yang dampaknya terhadap umat manusia bahkan alam semesta secara keseluruhan. ${ }^{25}$ Sedangkan menurut al-Maragy bahwa Jibril memperlihatkan dirinya kepada Rasulullah saw. dan pada waktu itu ia berada pada ufuk yang tinggi, yakni ufuk tempat terbitnya matahari. Kemudian Jibril memulai mendekatkan diri kepada Muhammad saw. lalu terus mendekat dan semakin turun sehingga dekatnya kepada Muhammad saw. sekitar dua busur atau lebih dekat lagi dari itu menurut ukuran pada umunya. Kemudian Jibril menyampaikan wahyu kepada Muhammad saw. sesuai dengan kehendak Allah untuk diwayukan kepadanya tentang masalah-masalah agama. ${ }^{26}$ Bahwa setelah Jibril sudah berdekatan benar dengan Muhammad saw., kemudian Jibril menyampaikan wahyu Allah swt. ${ }^{27}$

Dari uraian di atas dipahami bahwa, Jibril ketika menyampaikan atau mengajarkan wahyu kepada Muhammad saw. secara fisik dekat kepada Nabi, sekalipun tetap ada batasnya, yakni sebatas dua busur anak panah. Hal ini menjadi pelajaran bagi siapapun yang berfungsi sebagai subjek pendidikan, bahwa seorang pendidik seharunya dekat kepada peserta didiknya baik dari segi fisik maupun jiwanya, tetapi tetap harus ada batas-batas tertentu, sehingga tetap terjaga kewibawaan dan kharismatik seorang pendidik. Seorang pendidik yang tidak memiliki kewibawaan dan kharismatik, pada umumnya pelajaran yang disampaikan, tidak berberkah bagi peserta didiknya, boleh jadi karena faktor penghargaan peserta didik kepada pendidiknya atau gurunya menyebabkan ilmunya tidak berberkah.

Karena itu, kedekatan seorang pendidik kepada peserta didiknya, harus didasari dengan sikap penghormatan kepada pendidik dan kasih sayang kepada peserta didik. Kedua sikap ini akan muncul dalam suasana pembelajaran, ketika pendidik dan peserta didik memiliki sikap tawadhu' atau rendah hati sebagai mana yang ditunjukkan oleh Jibril sebagai pendidik ketika itu dan Muhammad saw. sebagai anak didiknya atau objek pendidikan. Menurut Ramayulis, tawadhu' merupakan sifat terpuji yang dapat mengantarkan pendidik kepada kemualiaan dan keagungan. ${ }^{28}$ Lebih lanjut beliau mengemukakan bahwa dalam rangkah mengimplementasikan sikap tawadhu', seoprang pendidik harus memperhatiakan:

a. Pendidik harus mengetahuai bahwa sikap sombong telah musnah bersamaan dengan kekhadiran ajaran Islam;

b. Pendidik harus melatih diri untuk bersikap tawadhu', lemah lembut dalam bergaul, baik dalam sikap maupun ucapan;

c. Pendidik harus percaya bahwa dengan sikap tawadhu' dalam bergaul akan memperoleh penghargaan dan penghormatan dari mereka;

d. Sikap tawadhu', tidak akan menjatuhkan harga diri, yang menyebabkan orang lain berbuat sewenang-wenang kepadanya;

\footnotetext{
${ }^{25}$ M. Quraish Shihab, Tafsir Al-Misbah, Vol. 13, h. 412 - 414

${ }^{26}$ Ahmad Mushthafa al-Maragy, Tafsir al-Maragy, jilid 27, h. 47

${ }^{27}$ Kementerian Agama RI. Al-Qur'an dan Tafsirnya, Jilid 9, h. 532

${ }^{28}$ Ramayulis, Propesi dan Etika Keguruan, h, 67
} 
e. Pendidik harus berupaya menanamkan sikap tawadhu' kepada orang lain, terutama kepada peserata didiknya, agar bisa menjadi teladan yang baik. ${ }^{29}$

Dengan demikian, sikap tawadhu' menjadi penting bagi seorang pendidik dalam bergaul dan berkomunikasi dengan peserta didik, namum tetap dalam batas-batas kewajaran, sehingga wibawanya tetap terjaga dan harga dirinya tetap terpeliharan serta ilmu yang disampaikan menjadi penuntun bagi peserta didiknya. Seorang pendidik tidak boleh terjangkiti dengan sikap sombong, takabbur apalagi kecongkakan ilmiah, agar peserta didiknya tidak menjauh darinya yang menyebabkan musnahnya penghargaan penghormatan kepada pendidinya. Karena itu, Ali bin Abi Thali (khalifah ke empat dari khulafa al-Rasyidin) telah berwasiat:

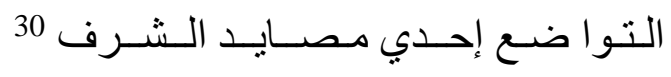

"Artinya: Rendah hati termsuk salah satu cara untuk mendapatkan kemuliaan"

Seorang pendidik yang memiliki intgritas keilmuan dan kepribadian yang mumpuni, termasuk sikap tawadhu' akan dikenan dan dimuliakan serta tidak dilupakan selama-lamanya. Dari sinilah kemudian muncul istilah "tidak ada bekas Guru", namun tidak semua guru atau pendidik berada dalam ketegori tersebut. Jibril sebagai subjek pendidikan sebagaimana yang diuraikan dalam tulisan ini, membuktikan bahwa beliau memiliki integrita keilmuan dan kepribadian yang mumpuni, sehingga Muhammad saw. selalu mengingatnya sekalipun Jibril berbeda-beda penampilannya.

\section{5. مساكذب الفؤاد مسارائ (ma kazzab al-Fuad ma raa)}

(ma kazzab al-Fuad ma raa) Term kazzaba adalah fi'il al-madi yang berasal dari huruf kaf, zal dan ba yang berarti dusta atau lawan dari ucapan yang benar, ${ }^{31}$ bahwa setalah Nabi Muhammad saw. mengetahui Jibril dan mengenalinya, maka hatinya tidak pernah mendustakan sekalipun Jibril menampakkan dirinya dalam bentuk yang lain. ${ }^{32}$ M. Quraish Shihab menjelaskan bahwa Nabi Muhammad tidak pernah mendustakan dan mengingkari atau meragukan dan keliru menyangkut apa yang telah ia lihat dengan pandangan mata dan hatinya yakni Jiberil. ${ }^{33}$

Demikian tertenamnya pikiran dan perasaan Muhammad saw. terhadap malekat Jibril, setelah diajar dan dibimbing tentang al-Quran yang mengantar dirinya menjadi Nabi dan Rasul. Hal ini menjadi pelajaran bagi pendidik agar selalu berusaha meninggalkan kesan terhadap peserta didiknya, khususunya ilmu pengetahuan, dan kepribadian yang baik sehingga tidak pernah dilupakan oleh peserta didiknya, sekalipun posisi berubah, penampilan dan bentuk fisik berubah karena faktor usia, tetap terbayang di pikiran peserta didiknya, itulah kenikmatan yang hakiki diperoleh seorang pendidik, ibarat dagangan yang tidak pernah rugi, modal tidak pernah berkurang bahkan bertambah terus, menyenangkan dan menetramkan jiwa bagi pemiliknya.

\section{SIMPULAN}

Kehadiran Malaikat Jibril dalam posisinya sebagai subjek pendidikan, harusnya menjadi inspirasi bagi mereka yang menjadi subjek pendidikan atau pendidik, terutama dari segi kecerdasan intelektualnya, kecerdasan emosionalnya dan kecerdasan spritaualnya. Jibril memiliki kecerdasan intelektual, yakni memiliki akal yang kuat, wawasan yang luas dan kuat hapalannya, sehingga apa yang diterima dari Allah swt. untuk disampaiakan kepada Nabi Muhammad saw. tidak terdapat perubahan sedikitpun, Karena itu, semua penyampaian atau pembelajaran yang diberikan kepada Muhammad saw. adalah sesuatu yang valid, tidak boleh ada keraguan sedikitpun di dalamnya, karena bersumber dari Allah Yang Maha Agung, disampiankan oleh malaikat yang cerdas, dan diterima oleh Nabi Muhammad saw. sebagai nabi yang mulia. Demikian halnya dari segi kecerdasan emosional, Jibril telah menunjukkan sikap keteladan yang baik terutama dari segi sikap renadah hati atau tawadu'.

\footnotetext{
${ }^{29}$ Ramayulis, Propesi dan Etika Keguruan, h, 68

${ }^{30}$ Syaikh Fadhlullah al-Ha'iri, Al-Imam 'Ali mim Bayanihi wa Hikmihi, diterjemhkan oleh Tholib Anis dengan judul Tanyalah Aku Sebelum Kau Kehingan Aku: Kata-kata Mutiara Ali bin Abi Thalib (Cet. VII; Bandung: Pustaka Hidayah, 2009), h. 135.

${ }^{31}$ Abi al-Husain Ahmad bin Faris bin Zakariya, Mu'jam Maqayis al-Lugah, jilid V, h. 168

${ }^{32} \mathrm{Abi}$ al-Husain Ahmad bin Faris bin Zakariya, Mu'jam Maqayis al-Lugah, jilid II, h. 48

${ }^{33}$ M. Quraish Shihab, Tafsir Al-Misbah, Vol. 13, h. 413
} 
Ketika beliau ingin berkomunikasi dengan Nab Muhammad saw. Jibril mendekati Nab Muhammad saw, sampai sebatas ukuran dua busur anak panah atau lebih dekat lagi, padahala boleh saja berkomunikasi sekalipun jibril berada di ufuk yang tinggi (tempat terbitnya matahari). Sedangkan kecerdasan spiritual, Jibril selaku berkomunikasi dengan Allah sebagai bagian dari ibadahnya, karena semua yang akan disamikan kepada Muhammad saw. sepenuhnya bersumber dari Allah SWT.

\section{DAFTAR PUSTAKA}

Ahmad bin Faris bin Zakariya, Abi al-Husain. Mu'jam Maqayis al-Lugah. Dar al-Jil: Bairut, 1420 H./1999 M.

Damin, Sudirman. Inovasi Pendidikan dalam Upaya Peningkatan Profesionalisme Tentang Kependidikan. Cet. I; Jakarta: Pustaka Setia, 2002

Departemen Agama RI. Al-Qur'an dan Terjemahnya. Toha Putra: Semarang, 2002

al-Ha'iri, Syaikh Fadhlullah. Al-Imam 'Ali mim Bayanihi wa Hikmihi, diterjemhkan oleh Tholib Anis dengan judul Tanyalah Aku Sebelum Kau Kehingan Aku: Kata-kata Mutiara Ali bin Abi Thalib. Cet. VII; Bandung: Pustaka Hidayah, 2009

Imron, Ali. Semiotika Al-Qur'an Metode dan Aplikasi Terhadap Kisah Yusuf. Cet I; Yogyakarta: Sukses Offset, 2011

Kementerian Agama RI. Al-Qur'an dan Tafsirnya, Jilid 9. Jakarta: Lentera Hati Abadi, 2010

al-Maragy, Ahmad Mushthafa. Tafsir al-Maragy, jilid 27. Mushthafa al-Bab al-Halabi: Mesir, t.th

al-Mahally, Jalal al-Din Muhammad bin Ahmad dan Jalal al-Din 'Abdu al-Raham bin Aby Bakar alSuyuty. Tafir al-Qur'an al-Karim. al-Sikapiyyah: Surabaya, t.th

al-Qurasyy al-Dimsyqy, 'Imad al-Din al-Fidai Isma'il ibn Katsir. Tafsir Al-Qur'an al- 'Azhim, Jilid 4. t.tp: Dar al-Fikr, t.th

Ridha, Rasyid. Al-Tarbiyah al-Islamiyah al-Ta'lim al-Islamiyah, XXXIV No. 7 .t.t: al-Manar, 1935

Ramayulis. Profesi dan Etika Keguruan. Cet. VII; Radar Jaya Offset: Jakarta, 2013

Shihab, M. Quraish. Tafsir Al-Misbah Pesan, Kesan dan Keserasian Al-Qur'an, Vol. 13. Cet. III; Letera Hati: Ciputat- Tangerang, 2005

Suyanto dan Asep Jihad. Menjadi Guru Profesional Strategi Meningkatkan Kualifikasi dan Kuslitas Guru di Era Globa. Gapprint: Jakarta: 2013

Takdir Ilahi, Muhammad. Revitalisasi Pendidikan Berbasis Moral. Cet. I; Jogjakarta: Ar-Ruzz Media, 2012 